\title{
Estimating rodent losses to stored rice as a means to assess efficacy of rodent management
}

\author{
Steven R. Belmain ${ }^{\mathrm{A}, \mathrm{E}}$, Nyo Me Htwe ${ }^{\mathrm{B}, \mathrm{D}}$, Nazira Q. Kamal ${ }^{\mathrm{C}}$, and Grant R Singleton ${ }^{\mathrm{D}}$
}

${ }^{A}$ Natural Resources Institute, University of Greenwich, Central Avenue, Chatham Maritime, Kent ME4 4TB; ${ }^{B}$ Plant Protection Division, Department of Agriculture, Yangon, Myanmar; ${ }^{C}$ Association for Integrated Development Comilla, Raghupur, Rajapara, Comilla-3500 Bangladesh; DInternational Rice Research Institute, Crop \& Environmental Sciences Division, DAPO Box 7777, Metro Manila, Philippines

${ }^{E}$ Corresponding author. Email: s.r.belmain@gre.ac.uk

\section{Abstract}

Context. Post-harvest losses by rodents have traditionally been calculated by estimates of consumption determined in the laboratory. Methods for assessing storage losses by rodents under small-holder conditions will help farmers and policy makers understand the impact rodents may have on food security, nutrition and health. Stored product loss assessment methods could also be used to monitor the effects of rodent control in villages.

Aims. The present study examined a method to measure the amount of rice eaten by rodents in household granaries. The effects of trapping and better hygiene around granaries to reduce rodent populations were investigated using the post-harvest monitoring method to determine whether the programme was successful in lowering rodent numbers sufficiently to reduce post-harvest losses.

Methods. Baskets with known quantities of rice were placed within household granaries and periodically monitored for moisture content, weight loss, faecal contamination and percentage of rodent-damaged grains. Using an empirical treatment-control study, rodent management was carried out at the community level through daily trapping in two Bangladesh villages and in Myanmar at the granary storehouse level. Post-harvest losses were monitored in villages/granaries with rodent management and in similar villages/granaries where there was no management.

Key results. Estimates of household losses in the absence of rodent control were $2.5 \%$ in Bangladesh and $17 \%$ in Myanmar. These losses were reduced when rodent control was implemented, down to $0.5 \%$ in Bangladesh and 5\% in Myanmar.

Conclusions. The impact of rodents on small-holder storage can be accurately assessed in the field under realistic conditions. Intensive daily trapping at the community level together with improved hygiene practices can successfully reduce rodent numbers and this can significantly reduce stored grain losses and rodent contamination and damage levels.

Implications. In addition to the threat of rodent pests during crop production, rodents are a major threat to food security after harvest and have, as of yet, unquantified impacts on household nutrition and health through potential transmission of gastro-enteric diseases and zoonoses to householders 
and domestic livestock. Trapping and environmental management are affordable and effective tools to reduce rodent impacts on stored grain within communities and are viable alternatives to rodenticides.

Additional keywords: post-harvest grain, stored product protection, Rattus, Bandicota, Mus, Suncus, rice, Bangladesh, Myanmar

\section{Introduction}

The science of estimating post-harvest losses caused by stored product insects has been strongly developed over decades of research that has optimised survey and detection methods, leading to standard operating procedures that allow accurate measurement of contamination levels, weight loss and quality assessment (Golob et al. 2008). Unfortunately, similar studies on the impact of rodents in post-harvest systems have not received the same level of attention (John 2014; Meyer 1994; Singleton 2003). Measuring the impact of rodents on stored grain is a challenge because rodents can physically remove grain from stores and also partially eat grains (Mdangi et al. 2013). It is also problematic to estimate the density of rodent populations in and around grain stores in villages or in urban areas because generally their nesting sites and foraging activities include other habitats.

Estimating rodent loss, damage and contamination to stored grain has typically been derived from the biology of rodent species, using generic food consumption/defecation rates to estimate potential loss/contamination of stored food for a given rodent population density (Ahmad et al. 1995; Proctor 1994). This kind of estimate may unfortunately bear little resemblance to actual losses within household food stores in the complex environments found across subsistence farming communities where rodents access several different food resources (Meyer 1994). Developing realistic measurements of rodent impacts on stored food is further complicated at the small-scale farming level as often grain movement in and out of store takes place on a daily basis, presenting challenges in how to measure rice removed by rodents vs. rice removed by people (Makundi et al. 2005). Although farmers will often observe faecal contamination on the surface of bulk stored grain in their house, or see holes chewed through grain sacks that lead to spillage of grain, it is not easy for a household to monitor the gradual process of grain removal by rodents to begin to understand the amounts of grain eaten by rodents. Knowing how much grain is lost to rodents may help incentivise farmers to invest more in developing rodent-proof granaries. Thus one of the objectives of the current study is to evaluate a potential method to monitor actual rodent losses to stored rice within smallscale household granaries. 
Rodent management in most subsistence agricultural communities can be described as ad hoc use of rodenticides (Makundi and Massawe 2011; Singleton et al. 2007). These un-coordinated attempts to control rodent populations are often too little, too late, and many farmers develop a sense of apathy and tolerance of rodents through failure to observe much improvement in rodent damage levels (Palis et al. 2007). At the household level where food is stored, several surveys have shown that rodents are considered a problem, chewing through clothes and blankets, disturbing sleep, biting people and contaminating food stores (Aplin et al. 2006; Garba et al. 2013; Stuart et al. 2011; Yonas et al. 2010). Actions to manage rodents around households often involve keeping a domestic cat, or ad hoc poisoning or trapping (Brown et al. 2008; Capizzi et al. 2014). Although Langton et al. (2001) reported that dwellings with pets had higher numbers of rats and mice in urban habitats in the UK. Therefore, as a second objective of the study, we tested whether coordinated community action through intensive trapping in houses could be an effective way to reduce rodent numbers at the village or granary level (Taylor et al. 2012). We hypothesis that rodent impacts to stored food would be lower, as measured by the method we developed for assessing losses in household grain stores, in villages where intensive trapping was conducted.

\section{Materials and Methods}

\section{Study area}

Research trials in Bangladesh were carried out over 2009 and 2010 across six regions in the North (Haripur), North-east (Purbadhala), North-west (Shibgonj), South-west (Kaliganj), Central-west (Mirpur) and South-east (Chandina, Barura, Laksham, Anandapur) of the country (Fig 1). Despite all regions remaining part of the same delta convergence of the Ganges and Brahmaputra rivers, experiencing similar temperatures and monsoonal rainfall cycles with similar habitats and reliance on small-scale rice cropping, there are regional differences in culture, poverty levels and diversity of crops grown. Study sites were chosen in order to try to reflect as much diversity as possible in order to compare potential differences in rodent ecology and damage. In Myanmar, research trials were conducted in 2007 and 2013 in the South within the main rice growing area of the Ayeyarwaddy Delta in the townships of Ma-ubin, Daik-U, and Myaungmya all with similar temperatures, rainfall and agroecological habitat (Fig 1).

In common to both countries, there are 2-3 crops per year depending on availability of irrigation during the dry season and the duration of flood water after the monsoon, both of which can limit the length of the growing season. Relatively minor changes in land elevation around villages and proximity to irrigation sources significantly affects the number of crops grown in different fields around villages. The main crop in both countries is rice; farmers in Bangladesh may rotate with wheat 
or vegetables during the dry season whilst Myanmar farmers may rotate with pulses. Farm size in Bangladesh is typically less than one hectare, whereas in Myanmar, those farmers who store rice typically cultivate 6-7 ha. This difference in scale of production has implications on how rice is stored after harvest at the household level. In Bangladesh, paddy rice (unthreshed rice) is typically stored inside the main building of the household in a granary constructed of woven bamboo and wood, which is sometimes plastered with mud and usually remains uncovered (Fig 2a). These bins may be circular or rectangular, are often placed on raised wooden platforms and vary in size from $0.5-5.0 \mathrm{~m}^{3}$, typically holding 0.5 - 5.0 t of paddy rice. Very small-scale farmers or landless households often store their rice in woven poly or jute sacks in bedrooms or other living areas of their house. In Myanmar, rice storage is typically within separate purpose-built household granaries or communal granaries (Fig 2b). These buildings are typically built of woven bamboo and wood with a thatched roof and range in size from $10.0-25 \mathrm{~m}^{3}$ with an average holding of $20 \mathrm{t}$. Paddy rice is often stored loosely within as a bulk granary, with paddy only being put in sacks if taken to market.

\section{Stored rice loss assessment}

The same method was used for all trials in Bangladesh and Myanmar during all storage seasons and is based on the methodology developed and reported by Belmain et al. (2006) and used by Brown et al. (2013). Small baskets made of woven reeds and bamboo commonly found throughout South Asia were purchased from local markets. All baskets had a base diameter of $28-30 \mathrm{~cm}$, a diameter of $41-43 \mathrm{~cm}$ at the open top and a depth of $11-13 \mathrm{~cm}$ (Fig $2 \mathrm{c}-\mathrm{d}$ ). When each basket is filled with $8 \mathrm{~kg}$ of paddy rice, the depth of rice in the basket is approximately $9 \mathrm{~cm}$ with an approximate exposed surface area of paddy of $1452 \mathrm{~cm}^{2}$ when baskets are filled. In Myanmar, two baskets were placed in each grain store. One was open to rats, the other had open weave gauze over the top to prevent rodent entry. The latter closed basket provided a measure of moisture loss or gain from the ambient air by rice in the basket. In Bangladesh, moisture content was determined using a portable grain moisture meter (MTPro, AgraTronix, USA).

As potential changes in moisture content could affect the weight of the rice in the basket, weight losses were corrected for moisture content as follows. All results are reported as the adjusted weight.

$W_{a}=W_{f} \times\left(\frac{M_{1}}{100}\right)+W_{f}$ and $M_{l}=\frac{W_{i}-W_{f}}{W_{i}}$

where

$W_{a}=$ adjusted weight 
$W_{f}=$ final weight

$\mathrm{W}_{\mathrm{i}}=$ initial weight

$M_{1}=$ moisture loss

In collaboration with local communities, households were randomly selected for involvement in trials. However, households had to have storage facilities and store sufficient quantities for their own rice stocks to last for several months. The dimensions of each farmer granary were recorded to calculate their volume and exposed surface area. All household members understood that baskets of rice would be placed in their rice stores on top of their own grain and that care should be taken when removing their own grain so that the basket should not spill or that farmer's own stocks did not spill in to the basket. In Bangladesh, trials in 2009 were carried out in five communities (Anandapur, Kaliganj, Mirpur, Purbadhala, Shibgonj) with 30 households randomly selected in each community. The storage season for this trial was from February to May 2009. In 2010, four Bangladeshi communities were involved in loss assessment trials (Haripur, Chandina, Barura, Laksham) with 16 households randomly selected in each community over the storage season of June to September 2010. In Myanmar in 2007, one community was selected (Myaungmya) with 10 household granaries randomly selected and the trial starting in May and ending in August 2007. The dimensions of each granary were recorded to estimate potential losses to the entire amount of rice stored. In the 2013 trials in Myanmar, three communities were selected (Daik-U Phaung Wei, Ma-ubin Pan Pin Su, Maubin Nyaung Wine) with 10 household granaries randomly selected per community, storing over the period of February to August 2013.

Data were collected every two weeks. Locally available spring scales typically used by market traders to weigh up to $10 \mathrm{~kg}( \pm 1 \mathrm{~g})$ were calibrated with an empty basket and then used to weigh each basket to determine potential weight loss from the original $8 \mathrm{~kg}$ of rice. A standard cup (approx. 500 g) was used to collect a subsample of grain from each basket. All faecal pellets were counted from the cup and 100 rice grains were randomly selected to count the number of grains undamaged/damaged by rodents. Rodent damage is distinguished by selective removal of the rice germ. All rice and faeces were returned to the basket, the basket content was topped up to $8 \mathrm{~kg}$ and then placed back inside the granary.

\section{Rodent control}

Rodent management actions were carried out in Bangladesh during 2010 in the villages of Barura and Laksham; no coordinated trapping was conducted in the other two villages. Rodent control consisted of the distribution of 200 kill traps ( $14 \times 7 \mathrm{~cm}$, Big snap-e, Kness Mfg., USA) in each community so that all households in each community had at least one trap. Households were instructed on how to set 
and place the traps inside their homes and told to set the traps every day in the evening. Research staff visited the households each morning to count and identify the rodent species captured according to (Aplin et al. 2003). Intensive daily trapping by the community commenced two months before the storage trial and carried on throughout the storage period for a total of six months trapping (April to September 2010).

In Myanmar, rodent management actions were implemented at the level of the rice storehouse with 5 out of the 10 storehouses in Myaungmya. These instructions involved setting Kness kill traps in and around the storehouse, improving rodent proofing of the storehouses, and sanitation. Sanitation included cutting down vegetation within $5 \mathrm{~m}$ of the storehouse and continuously maintaining that area free of vegetation and household garbage. The building structure was regularly inspected for any obvious holes or cracks in storehouse walls which were quickly repaired. Killtrapping involved Kness traps inside the stores and bamboo snare traps outside the stores where five of each type were set for two consecutive nights every two weeks. We recorded the number and species of rodents captured, and the sex and weight of each individual. This management strategy commenced at the beginning of the rice harvest period and was maintained throughout the storage period (May to August 2007).

Based on field identifications, voucher specimens were collected for taxonomic identification, and species were confirmed mostly through anatomical features backed up by DNA analysis where necessary (Aplin et al. 2003). All research was approved by the ethics committees of the University of Greenwich (Bangladesh) and the International Rice Research Institute (Myanmar) and followed the guidelines of the American Society of Mammalogists (Sikes and Gannon 2011).

\section{Data analysis and farm loss calculations}

Rodent daily capture rates in Bangladesh and 2-weekly capture rates in Myanmar were compared by ANOVA with post-hoc HSD to determine potential differences between villages and month of capture. For both countries, loss, damage and contamination rates among communities were analysed using a repeated measures ANOVA, which also enabled comparison between villages/granaries with rodent control and villages/granaries with no rodent control. Regression analyses were performed on the rate of loss from baskets using weight loss between sampling intervals to determine best fit models, by their $\mathrm{R}^{2}$ values, to explain grain loss over time. All analyses were carried out using XLSTAT version 2014.3.02 (Addinsoft, France).

As the loss of rice by rodents is partly related to the exposed surface area that rodents have access to, we estimated the potential losses to farmer stores based on a direct relationship between the surface area of the rice in the experimental basket and the surface area of each farmer store. 
These estimates are based on an assumption that the rice in the basket and farm store is equally attractive to rodents and that rodents gaining access to the farmer store where the baskets are placed are as likely to remove grain from the basket as anywhere else on the surface of the stored grain. We accept this assumption is open to dispute; it nevertheless provides a means of directly computing the amount of grain being consumed by rodents in the farm store as follows. The weight of grain lost is plotted to provide a rate of rice removal by rats over time and from this it is possible to calculate a daily rate of loss in $\mathrm{g} / \mathrm{cm}^{2}$. The rate of loss is a function of the numbers of rodents feeding in a given granary, and as presented below in the results, different loss rates can be observed in relation to rodent abundance.

\section{Results}

\section{Rodent captures}

In Bangladesh, the number of rodents captured inside people's homes was significantly higher during the first month of trapping, after which trap success declined and remained low throughout the trial (ANOVA, df $=5, \mathrm{SSQ}=92.86, \mathrm{~F}=29.67, \mathrm{P}<0.0001$, Table 1). Rattus rattus and Bandicota bengalensis were the most abundant rodents captured in Bangladesh. In Myanmar, a similar range of species was captured in and around granaries as observed in Bangladesh with the exception that no Mus species were captured (Table 1). Bandicota bengalensis was the most abundant rodent species captured in Myaungmya, Myanmar, and the trap success was not significantly different throughout the duration of trapping (ANOVA, $d f=5, S S Q=15.96, F=0.75, P=0.59$ ).

\section{Crop loss, contamination and damage}

During the 2009 trial in Bangladesh all communities experienced similar losses, with $0.5-1.0 \mathrm{~kg}$ lost from the basket within the first month of storage, $1.2-2.2 \mathrm{~kg}$ lost after two months and $1.8-3.2 \mathrm{~kg}$ lost by 3 months (Fig 3a). All five villages experienced similar cumulative losses over time (repeated measures ANOVA, df = 9, SSQ = 840.81, $F=99.53, P<0.0001)$. Some villages recorded losses over shorter storage durations than others, and this was largely because farmer stores were emptied more quickly due to a combination of smaller quantities of grain initially stored and/or selling grain for income. With no grain in the farmer granary, the rice in the basket experiences much higher rates of loss. In Anandapur, Kaliganj and Mirpur loss rapidly increased over the last two weeks as many farm stores around the community were already empty, thus increasing feeding pressure from remaining stores still containing grain. Contamination (repeated measures ANOVA, $\mathrm{df}=9, \mathrm{SSQ}=30195.56, \mathrm{~F}=$ 47.94, $\mathrm{P}<0.0001$, Table 2 ) and damage (repeated measures ANOVA, $\mathrm{df}=9$, SSQ $=29002.09, \mathrm{~F}=70.92$, $\mathrm{P}<0.0001$, Table 2) rates followed similar cumulative changes over time among the five communities. In Myanmar 2013 trials, the cumulative loss also was generally comparable among the three 
communities (Fig 3b, repeated measures ANOVA, $d f=7, S S Q=11.65, F=22.65, P<0.0001$ ). Faecal contamination (Table 2 ) and damage rates (Table 3 ) did not appear to follow any trend, were highly variable and generally very low in comparison to Bangladesh data.

In 2010, grain loss, damage and contamination rates in Bangladesh were significantly higher in the villages of Haripur and Chandina, where there was no systematic rodent control implemented at the community level in comparison to the villages of Laksham and Barura where all households in the community were trapping every day (Fig $4 \mathrm{a}$, repeated measures ANOVA, $\mathrm{df}=3, \mathrm{SSQ}=36.71, \mathrm{~F}=$ 27.19, $\mathrm{P}<0.0001$ ). Data showing faecal contamination (Table 2 , repeated measures ANOVA, $d f=3$, $\mathrm{SSQ}=19738.31, \mathrm{~F}=9.78, \mathrm{P}<0.0001)$ and damage $($ Table 3 , repeated measures $\mathrm{ANOVA}, \mathrm{df}=3, \mathrm{SSQ}=$ $2748.94, F=17.48, P<0.0001$ ) supported the same differential observation between communities that were intensively trapping and communities that were not intensively trapping.

For Myanmar trials in 2007, the grain stores where rodent control was implemented had significantly lower rates of loss (Fig 4b), contamination (Table 2 ) and damage (Table 3 ) than the granaries where no coordinated management activities were implemented (repeated measures ANOVA, $d f=1, S S Q=6.13, F=140.10, P<0.0001)$. During three and half months of storage, the mean grain loss from baskets by rodents in treatment sites was $6 \%$ and up to $17 \%$ in control sites.

\section{Estimating rodent impact on farm stored rice}

Using 2010 trial data from Bangladesh, the rate of loss between each assessment interval was calculated for communities that were intensively trapping and those that were not (Fig 5). Regression analysis performed on these loss rates showed that the best fit regression by $R^{2}$ values was linear in all four villages with similar slopes close to zero (ANCOVA, $d f=7, \mathrm{SSQ}=34.67, \mathrm{~F}=8.86, \mathrm{P}<0.0001$ ). Although the loss rate was relatively variable over time, the regression justified calculating a mean daily loss rate for communities that set traps and for those that did not trap. For communities that were intensively trapping, the mean daily loss was $0.13 \pm 0.052 \mathrm{~kg} /$ day and the communities not trapping experienced a loss rate of $0.59 \pm 0.146 \mathrm{~kg} /$ day. Thus based on a basket surface area of 1452 $\mathrm{cm}^{2}, 0.0066 \pm 0.00134 \mathrm{~g} / \mathrm{cm}^{2}$ and $0.0293 \pm 0.00466 \mathrm{~g} / \mathrm{cm}^{2}$ of grain was lost each day in trapping communities and non-trapping communities, respectively. The dimensions of each farmer store were used to calculate a mean granary surface area of $0.905 \pm 0.06162 \mathrm{~m}^{2}$ and mean granary volume of $1.537 \pm 0.1916 \mathrm{~m}^{3}(\mathrm{n}=64)$. Using the farmer's granary surface area and the rate of loss calculated in $\mathrm{g} / \mathrm{cm}^{2}$ from the basket, the amount of grain lost in an average farmer store could be calculated (Table 4).

The surface area of grain stored inside granaries in Myanmar makes similar calculations more difficult. This is because the area of the granary is much larger and often the grain does not cover the 
entire floor of the granary, with grain being piled in the middle or a corner providing an uneven surface area. Therefore, there is not necessarily a direct relationship between the granary floor area and surface area of grain. In 2007, researchers worked with farmers to ensure their grain stores were kept with a level surface area. Therefore, using the same calculations as for Bangladesh, it was possible to calculate a daily rate loss of $0.87 \mathrm{~g} / \mathrm{cm}^{2}$ in treatment granaries and $1.47 \mathrm{~g} / \mathrm{cm}^{2}$ in control granaries. The mean amount of rice stored in this region of Myanmar is $19,855 \mathrm{~kg}(n=10)$. Thus a $6 \%$ loss in granaries implementing rodent control (treatment) is equal to $993 \mathrm{~kg}$ and a $17 \%$ loss in granary not managing rodents (the control) is equal to $3,375 \mathrm{~kg}$. Therefore, the amount of grain lost in Myanmar granaries was higher than in Bangladesh granaries (Table 2).

\section{Discussion}

Rodents are a significant problem for the safe storage of commodities at the small-holder level in Bangladesh and Myanmar. The few similar on-farm studies carried out in Africa (Mdangi et al. 2013) and Asia (Brown et al. 2013) broadly support this conclusion. Existing storage structures used in Bangladesh and Myanmar are clearly not rodent-proof leading to significant levels of loss, damage and contamination that contributes to food insecurity, poor nutrition (seed germ removal), and potential disease transmission through rodent urine, faeces and saliva. Unprotected food stores will increase the numbers of rodents foraging, surviving and living in close co-habitation with humans, and encouraging high numbers of rodents in close proximity to human habitation is likely to contribute to zoonotic disease transmission. There is growing evidence that the harvesting and storage of food encourages rodents in households and drives zoonosis transmission dynamics for Lassa fever (FichetCalvet et al. 2007) and plague (Laudisoit et al. 2007) in rural communities in Africa and for Leptospirosis in urban slum environments in South America (Felzemburgh et al. 2014; Maciel et al. 2008). In the plague foci of the south-western United States, Mann et al. (1979) indicated plague cases were largely because of "entry of the reservoir host into the habitat of the human rather than from entry of the human into the sylvatic habitat of the reservoir host". Although several diseases are known to be spread through rodent urine, saliva and faeces (Meerburg et al. 2009) we did not screen stored rice for the presence of viruses, bacteria, eggs or cysts, and it is generally unknown whether such rodent contamination leads to human or domestic livestock health issues, particularly at the small-holder farmer level. As these storage conditions are prevalent across many developing countries (Proctor 1994), we believe these interactions between rodents, food stores and human/livestock health are an important area for future research in order to fully understand the socio-economic impact of rodents and inform the priorities of rural development programmes. 
The data collected across several communities in two countries and two storage seasons suggest small mammal diversity is remarkably high inside rural villages. Most of the species could be categorised as commensal species, with the exceptions, perhaps, of Bandicota indica and Mus terricolor (Aplin et al. 2003). Although we are unable to provide definitive evidence on which of these species are resident in human households and species which may be foraging inside but living peridomestically, we can argue that the abundance data from Bangladesh would suggest four species are the main resident commensal small mammal species: $R$. rattus, B. bengalensis, $M$. musculus and the shrew S. murinus. The ability of the these four species to share the domestic environment would indicate some level of resource partitioning and niche separation, and discussions with householders would suggest $R$. rattus and $M$. musculus are living in the roof thatching or roof void whilst $B$. bengalensis burrows within the mud walls and floor of houses, and S. murinus lives mainly in kitchens in and around items stored on the floor. Commonly known as the Asian house shrew or Indian musk shrew, S. murinus are widely considered a domestic pest in South Asia due to their smell, attack of chicks, eggs and eating a wide variety of food in households, e.g. rice, potatoes, dried fish, and the shrew is a major invasive species (Seymour et al. 2005). The relatively lower numbers of $R$. exulans, $B$. indica and $M$. terricolor could suggest these species are living outside around villages. Discussions with householders support these distinctions with $R$. exulans predominantly living in trees, particularly coconut trees, $B$. indica living in bush/fallow land and $M$. terricolor burrowing around vegetable gardens. This high number of species living within these rural communities, particularly small and large species in the same areas, does suggest that food and harbourage are in abundance (Fox 1981). Further studies such as spooling or radio tracking could help elucidate potential inter-specific interactions important in the context of zoonosis and/or ecologically-based management (Monadjem et al. 2011; Stuart et al. 2007).

The significant changes in trap success in the villages of Barura and Laksham, Bangladesh provide strong evidence that rodent populations declined through trapping effort. Other potential reasons that could explain changes in trap success, such as farmers forgetting to set traps or the development of trap shyness, are not supported by discussions with communities. Communities rarely reported that the Kness traps were set off without capturing an animal, and researchers did carry out random checks to ensure traps were set every day. As there was no apparent resurgence in rodent numbers and farmers widely commented that there was much less noise in their houses at night and fewer rat bites, we argue that our trap success data are an accurate representation of changes in rodent populations. Furthermore, significantly lower levels of loss, contamination and damage of stored rice were observed in these two communities when compared to two other very similar communities where community-based rodent trapping did not occur (Haripur and Chandina). A similar 
change in reduction of loss to stored rice was observed in Myanmar where the rodent control operations were confined to the immediate vicinity of granary structures, again providing evidence that rodent management actions had a positive impact to protect stored rice from rodents. However, despite the significant impact of rodent management on the loss of stored rice in granaries in Myaungmya, trap success did not change in Myanmar. This is likely due to the scale of management operations being limited to the granary and environs, thus having little impact on the rodent population in the village and potential immigration from other granaries and houses.

The losses in farm stores by rodents were remarkably high in Myaungmya in comparison to villages in Bangladesh. This could mean that our surface area calculations require further refinement, e.g. accounting for the relative size of the basket surface area compared to increasingly larger farm stores. This is highlighted by the fact that higher amounts of rice were lost from baskets in Bangladesh than in Myanmar, but because farm stores have relatively smaller surface areas in Bangladesh the overall loss from the farm store is lower in Bangladesh than in Myanmar. Thus the ratio of surface area in farm store and sampling basket may affect our calculations, and future research should try to involve a broader range of farm store sizes to understand this potential dynamic. In 2013, the Ma-ubin and Daik-U grain stores were larger but often the grain did not cover the surface area and was in piles rather than evenly spread. Nevertheless, the amount of grain taken by rodents from the baskets in Ma-ubin and Daik-U was less than half that taken in Myaungmya. Apart from the ratio of surface area of store to basket, the variation in level of losses among localities also may possibly reflect different cropping systems and socio-economic conditions. These findings highlight the need for stratified studies across different agricultural systems and regions to provide a better understanding at a national level of the level of post-harvest losses to rice caused by rodents. Such information is vital given how little quantitative data exists on rodent losses post-harvest to cereals (John 2014) and the concerns on food security in coming decades given the projected world population growth: "By 2030, food demand is predicted to increase by $50 \%$ (70\% by 2050)" (United Nations 2014).

Both acute and anticoagulant rodenticides are available and used in Bangladesh and Myanmar, although generally in low quantities in an uncoordinated, ad hoc manner when serious problems are observed (Singleton et al. 2007; Singleton 2003). Poison use around households where food is stored does raise safety issues, particularly with hoarding species such as $B$. bengalensis that may inadvertently move poison baits around inside households to unexpected locations, e.g. inside granaries. Although trapping is argued to be labour intensive (Palis et al. 2007), our research shows that community coordinated trapping can be effective because labour is shared with relatively little expected of individuals, i.e. setting one trap every evening, and because it can act at an appropriate scale to limit immigration. However, as rodent immigration is inevitable, trapping must continue long- 
term, and our research suggests immigration can be kept in check through continuous trapping. Kill traps are relatively durable and could last for several years; their initial cost and need for coordination at the community level does mean communities need knowledge and extension support to implement appropriately.

Our research indicates that rural households in Bangladesh are losing more than $70 \mathrm{~kg}$ of rice per year, which is enough to feed a family member for another 3 to 4 months. The financial loss if this amount of rice was sold in local markets late in the season would equate to about 30 to 40 US dollars. Similarly, based on national per capita consumption, rice losses in Myanmar of $130 \mathrm{~kg}$ could feed another family member for 8 months (Maclean et al. 2013). Further studies on the multiple impacts (human/livestock health, food security and nutrition) of rodents living in rural communities and data on their socio-economic impact could help prioritise extension programmes and provide clear incentives to farmers to adopt rodent-proof granaries and to work together to coordinate rodent management actions at the community level.

\section{Acknowledgements}

Research in Bangladesh was supported by the Research Into Use Programme of the UK Department for International Development. Research in Myanmar was supported by the International Rice Research Institute and the Ministry of Agriculture and Irrigation, Myanmar with funding from the Swiss Agency for Development and Cooperation, and the Australian Centre for International Research and Development. We acknowledge the considerable technical support provided by Nazmul Kandry, Mohammed Harun and many NGO support staff in Bangladesh and U Than Aye, U Myo Myint, U Aye Tun, and other staff of the Department of Agriculture, Plant Protection Division in Myanmar. We sincerely thank all the farmers involved for their cooperation.

\section{References}

Ahmad, E., Hussain, I., and Brooks, J. E. (1995). Losses of stored foods due to rats at grain markets in Pakistan. International Biodeterioration \& Biodegradation 36, 125-133.

Aplin, K. P., Brown, P. R., Jacob, J., Krebs, C. J., and Singleton, G. R. (2003). "Field methods for rodent studies in Asia and the Indo-Pacific." (Australian Centre for International Agricultural Research, Canberra, Australia.)

Aplin, K. P., Brown, P. R., Singleton, G. R., Douang Boupha, B., and Khamphoukeo, K. (2006). Rodent ecology in the rice environments of Laos. In "Rice in Laos." (Eds J. M. Schiller, M. B. Chanphengxay, B. Linquist, and S. A. Rao.) pp. 291-308. (International Rice Research Institute, Los Banos, Philippines). 
Belmain, S. R., Meyer, A. N., Kamal, N. Q., Shafali, R. B., Singleton, G. R., Aplin, K., and Mian, Y. (2006). Ecologically based rodent management for rice-based cropping systems in Bangladesh. In "Perspectives on pests II: Achievements of research under the UK Department for International Development Crop Protection Programme, 2000-05." (Eds A. Sweetmore, F. Kimmins, and P. Silverside.) pp. 179-181. (Natural Resources International, Aylesford, UK).

Brown, P. R., McWilliam, A., and Khamphoukeo, K. (2013). Post-harvest damage to stored grain by rodents in village environments in Laos. International Biodeterioration \& Biodegradation 82, 104-109.

Brown, P. R., Yee, N., Singleton, G. R., Kenney, A. J., Htwe, N. M., Myint, M., and Aye, T. (2008). Farmers' knowledge, attitudes, and practices for rodent management in Myanmar. International Journal of Pest Management 54, 69-76.

Capizzi, D., Bertolino, S., and Mortelliti, A. (2014). Rating the rat: global patterns and research priorities in impacts and management of rodent pests. Mammal Review 44, 148-162.

Felzemburgh, R. D. M., Ribeiro, G. S., Costa, F., Reis, R. B., Hagan, J. E., Melendez, A. X. T. O., Fraga, D., Santana, F. S., Mohr, S., dos Santos, B. L., Silva, A. Q., Santos, A. C., Ravines, R. R., Tassinari, W. S., Carvalho, M. S., Reis, M. G., and Ko, A. I. (2014). Prospective study of leptospirosis transmission in an urban slum community: role of poor environment in repeated exposures to the Leptospira agent. PLoS Neglected Tropical Diseases 8, e2927.

Fichet-Calvet, E., Lecompte, E., Koivogui, L., Soropogui, B., Doré, A., Kourouma, F., Sylla, O., Daffis, S., Koulémou, K., and Meulen, J. ter (2007). Fluctuation of abundance and Lassa virus prevalence in Mastomys natalensis in Guinea, West Africa. Vector-Borne and Zoonotic Diseases 7, 119-128.

Fox, B. J. (1981). Niche parameters and species richness. Ecology 62, 1415.

Garba, M., Kane, M., Gagare, S., Kadaoure, I., Sidikou, R., Rossi, J.-P., and Dobigny, G. (2013). Local perception of rodent-associated problems in Sahelian urban areas: a survey in Niamey, Niger. Urban Ecosystems 17, 573-584.

Golob, P., Farrell, G., and Orchard, J. eds. (2008). “Crop Post-Harvest: Science and Technology, Crop Post-Harvest: Principles and Practice." (Blackwell Publishing, Oxford, UK.)

John, A. (2014). Rodent outbreaks and rice pre-harvest losses in Southeast Asia. Food Security 6, 249-260.

Langton, S. D., Cowan, D. P., and Meyer, A. N. (2001). The occurrence of commensal rodents in dwellings as revealed by the 1996 English House Condition Survey. Journal of Applied Ecology 38, 699-709.

Laudisoit, A., Leirs, H., Makundi, R. H., Dongen, S. Van, Davis, S., Neerinckx, S., Deckers, J., and Libois, R. (2007). Plague and the human flea, Tanzania. Emerging Infectious Diseases 13, 687-693.

Maciel, E. A. P., de Carvalho, A. L. F., Nascimento, S. F., de Matos, R. B., Gouveia, E. L., Reis, M. G., and Ko, A. I. (2008). Household transmission of leptospira infection in urban slum communities. PLoS Neglected Tropical Diseases 2, e154. 
Maclean, J., Hardy, B., and Hettel, G. (2013). "Rice Almanac, 4th edition: Source Book for One of the Most Important Economic Activities on Earth." (International Rice Research Institute, Los Banos, Philippines.)

Makundi, R. H., Bekele, A., Leirs, H., Massawe, A. W., and Mulungu, L. S. (2005). Farmer's perceptions of rodents as crop pests: Knowledge, attitudes and practices in rodent pest management in Tanzania and Ethiopia. Belgian Journal of Zoology 135, 153-157.

Makundi, R. H., and Massawe, A. W. (2011). Ecologically based rodent management in Africa: potential and challenges. Wildlife Research 38, 588.

Mann, J. M., Martone, W. J., Boyce, J. M., Kaufmann, A. F., Barnes, A. M., and Weber, N. S. (1979). Endemic human plague in New Mexico: Risk factors associated with infection. Journal of Infectious Diseases 140, 397-401.

Mdangi, M., Mulungu, L. S. L. S., Massawe, A. W. a. W., Eiseb, S. J., Tutjavi, V., Kirsten, F., Mahlaba, T., Malebane, P., von Maltitz, E., Monadjem, A., Dlamini, N., Makundi, R. H. R. H., Belmain, S. R., Eiseb, Seth, J., and Maltitz, E. Von (2013). Assessment of rodent damage to stored maize (Zea mays L .) on smallholder farms in Tanzania. International Journal of Pest Management 59, 5562.

Meerburg, B. G., Singleton, G. R., and Kijlstra, A. (2009). Rodent-borne diseases and their risks for public health. Critical Reviews in Microbiology 35, 221-270.

Meyer, A. N. (1994). Food control practice: Food Stores. In "Rodent pests and their control." (Eds A. P. Buckle and R. H. Smith.) pp. 273-290. (CAB International, Wallingford, UK).

Monadjem, A., Mahlaba, T., Dlamini, N., Eiseb, S. J., Belmain, S. R., Mulungu, L. S., Massawe, A. W., Makundi, R. H., Mohr, K., Taylor, P. J., and Eiseb, Seth, J. (2011). Impact of crop cycle on movement patterns of pest rodent species between fields and houses in Africa. Wildlife Research 38, 603-609.

Palis, F. G., Singleton, G., Sumalde, Z., and Hossain, M. (2007). Social and cultural dimensions of rodent pest management. Integrative zoology 2, 174-83.

Proctor, D. L. ed. (1994). "Grain Storage Techniques: Evolution and Trends in Developing Countries, FAO Agricultural Services Bulletin \#109." (Food \& Agriculture Organisation, Rome, Italy.)

Seymour, A., Varnham, K., Roy, S., Harris, S., Bhageerutty, L., Church, S., Harris, A., Jennings, N. V., Jones, C., Khadun, A., Mauremootoo, J., Newman, T., Tatayah, V., Webbon, C., and Wilson, G. (2005). Mechanisms underlying the failure of an attempt to eradicate the invasive Asian musk shrew Suncus murinus from an island nature reserve. Biological Conservation 125, 23-35.

Sikes, R. S., and Gannon, W. L. (2011). Guidelines of the American Society of Mammalogists for the use of wild mammals in research. Journal of Mammalogy 92, 235-253.

Singleton, G. (2003). Impacts of rodents on rice production in Asia. IRRI Discussion Paper Series 45, $1-30$.

Singleton, G. R., Brown, P. R., Jacob, J., and Aplin, K. P. (2007). Unwanted and unintended effects of culling: A case for ecologically-based rodent management. Integrative zoology 2, 247-59. 
Stuart, A. M., Prescott, C. V., Singleton, G. R., and Joshi, R. C. (2011). Knowledge, attitudes and practices of farmers on rodent pests and their management in the lowlands of the Sierra Madre Biodiversity Corridor, Philippines. Crop Protection 30, 147-154.

Stuart, A. M., Prescott, C. V., Singleton, G. R., Joshi, R. C., and Sebastian, L. S. (2007). The rodent species of the Ifugao Rice Terraces, Philippines - target or non-target species for management? International Journal of Pest Management 53, 139-146.

Taylor, P. J., Downs, S., Monadjem, A., Eiseb, S. J., Mulungu, L. S., Malebane, P., Makundi, R. H., Lamb, J., and Belmain, S. R. (2012). Experimental treatment-control studies of ecologically based rodent management in Africa : balancing conservation and pest management. Wildlife Research 39, 51-61.

United Nations (2014). Water and food security | International Decade for Action "Water for Life" 2005-2015. Available at: http://www.un.org/waterforlifedecade/food_security.shtml [Verified 13 September 2014].

Yonas, M., Welegerima, K., Deckers, S., Raes, D., Makundi, R., and Leirs, H. (2010). Farmers' perspectives of rodent damage and management from the highlands of Tigray, Northern Ethiopian. Crop Protection 29, 532-539. 
Table 1. Small mammals captured inside houses in two villages over the period of April to September 2010 in Bangladesh and in and around 10 granaries in Myanmar over the period of May to August 2007

\begin{tabular}{|c|c|c|c|c|c|c|c|c|c|c|c|}
\hline Village & Date & $\begin{array}{c}\text { Trap } \\
\text { success } \\
(\%)\end{array}$ & $\begin{array}{c}\text { Total } \\
\text { captured }\end{array}$ & $\begin{array}{l}\text { Trap } \\
\text { nights }\end{array}$ & $\begin{array}{l}\text { Rattus } \\
\text { rattus }\end{array}$ & $\begin{array}{l}\text { Rattus } \\
\text { exulans }\end{array}$ & $\begin{array}{l}\text { Bandicota } \\
\text { bengalensis }\end{array}$ & $\begin{array}{l}\text { Bandicota } \\
\text { indica }\end{array}$ & $\begin{array}{l}\text { Suncus } \\
\text { murinus }\end{array}$ & $\begin{array}{c}\text { Mus } \\
\text { musculus }\end{array}$ & $\begin{array}{l}\text { Mus } \\
\text { terricolor }\end{array}$ \\
\hline \multirow{6}{*}{ Barura } & Apr-10 & 4.0 & 1990 & 12,960 & 524 & 9 & 534 & 11 & 179 & 731 & 2 \\
\hline & May-10 & 1.1 & 963 & 21,255 & 225 & 19 & 132 & 3 & 114 & 467 & 3 \\
\hline & Jun-10 & 0.5 & 688 & 28,020 & 132 & 18 & 62 & 12 & 107 & 346 & 11 \\
\hline & Jul-10 & 0.3 & 746 & 28,954 & 95 & 49 & 128 & 8 & 102 & 331 & 33 \\
\hline & Aug-10 & 0.3 & 612 & 28,954 & 78 & 5 & 111 & 13 & 85 & 293 & 27 \\
\hline & Sep-10 & 0.2 & 488 & 28,020 & 55 & 5 & 86 & 8 & 64 & 263 & 7 \\
\hline \multirow{6}{*}{ Laksham } & Apr-10 & 4.3 & 914 & 8,670 & 373 & 6 & 58 & 2 & 178 & 297 & 0 \\
\hline & May-10 & 3.7 & 901 & 8,959 & 332 & 1 & 39 & 1 & 112 & 415 & 1 \\
\hline & Jun-10 & 1.6 & 349 & 8,670 & 138 & 1 & 36 & 0 & 45 & 129 & 0 \\
\hline & Jul-10 & 0.7 & 223 & 8,959 & 63 & 1 & 17 & 4 & 38 & 98 & 2 \\
\hline & Aug-10 & 0.6 & 208 & 8,959 & 52 & 3 & 20 & 2 & 23 & 84 & 24 \\
\hline & Sep-10 & 0.5 & 136 & 8,670 & 41 & 1 & 22 & 9 & 20 & 34 & 9 \\
\hline \multirow{6}{*}{ Myaungmya } & 25-May-07 & 0.29 & 44 & 150 & 2 & 2 & 8 & 0 & 32 & 0 & 0 \\
\hline & 3-Jun-07 & 0.35 & 53 & 150 & 4 & 0 & 4 & 6 & 39 & 0 & 0 \\
\hline & 18-Jun-07 & 0.23 & 34 & 150 & 1 & 1 & 0 & 0 & 32 & 0 & 0 \\
\hline & 6-Jul-07 & 0.26 & 39 & 150 & 0 & 0 & 0 & 2 & 37 & 0 & 0 \\
\hline & 23-Jul-07 & 0.33 & 49 & 150 & 0 & 1 & 11 & 0 & 37 & 0 & 0 \\
\hline & 5-Aug-07 & 0.31 & 47 & 150 & 0 & 0 & 1 & 0 & 46 & 0 & 0 \\
\hline
\end{tabular}


Table 2. Mean ( \pm s.e.) number of rodent droppings in $500 \mathrm{~g}$ rice subsamples from baskets placed in farmer granaries in Bangladesh and Myanmar

\begin{tabular}{|c|c|c|c|c|c|c|c|c|c|c|c|c|c|c|}
\hline \multirow[b]{2}{*}{$\begin{array}{l}\text { Sampling } \\
\text { Interval }\end{array}$} & \multicolumn{5}{|c|}{ Bangladesh, Feb-May 2009} & \multicolumn{3}{|c|}{ Myanmar, Feb-Sep 2013} & \multicolumn{4}{|c|}{ Bangladesh, Jun-Sep 2010} & \multicolumn{2}{|c|}{ Myanmar, May-Aug 2007} \\
\hline & Anandapur & Kaliganj & Mirpur & Purbadhala & Shibgonj & $\begin{array}{c}\text { Ma-ubin } \\
\text { Nyaung } \\
\text { Wine }\end{array}$ & $\begin{array}{l}\text { Ma-ubin } \\
\text { Pan Pin Su }\end{array}$ & $\begin{array}{c}\text { Daik-U } \\
\text { Phaung } \\
\text { Wei }\end{array}$ & $\begin{array}{l}\text { Haripur } \\
\text { control }\end{array}$ & $\begin{array}{c}\text { Chandina } \\
\text { control }\end{array}$ & $\begin{array}{l}\text { Barura } \\
\text { treatment }\end{array}$ & $\begin{array}{l}\text { Laksham } \\
\text { treatment }\end{array}$ & $\begin{array}{l}\text { Myaungmya } \\
\text { control }\end{array}$ & $\begin{array}{c}\text { Myaungmya } \\
\text { treatment }\end{array}$ \\
\hline 0 & $0.0 \pm 0$ & $0.0 \pm 0$ & $0.0 \pm 0$ & $0.0 \pm 0$ & $0.0 \pm 0$ & $0.0 \pm 0$ & $0.0 \pm 0$ & $0.0 \pm 0$ & $0.0 \pm 0$ & $0.0 \pm 0$ & $0.0 \pm 0$ & $0.0 \pm 0$ & $0.0 \pm 0$ & $0.0 \pm 0$ \\
\hline 1 & $2.7 \pm 0.07$ & $7.7 \pm 2.06$ & $4.5 \pm 0.56$ & $1.8 \pm 0.21$ & $10.0 \pm 2.01$ & $2.3 \pm 0.56$ & $1.7 \pm 1.0$ & $0.2 \pm 0.02$ & $12.7 \pm 5.79$ & $24.3 \pm 3.78$ & $5.1 \pm 3.10$ & $1.6 \pm 0.95$ & $2.4 \pm 0.20$ & $0.0 \pm 0$ \\
\hline 2 & $6.7 \pm 1.12$ & $9.0 \pm-.93$ & $6.8 \pm 0.95$ & $3.6 \pm 0.29$ & $15.7 \pm 1.34$ & $1.7 \pm 0.67$ & $0.0 \pm 0.01$ & $0.6 \pm 0.28$ & $25.1 \pm 6.45$ & $35.9 \pm 5.63$ & $8.1 \pm 3.06$ & $1.2 \pm 0.63$ & $1.2 \pm 0.93$ & $0.0 \pm 0$ \\
\hline 3 & $12.1 \pm 1.66$ & $6.7 \pm 1.05$ & $8.7 \pm 0.88$ & $4.1 \pm 0.34$ & $17.1 \pm 1.81$ & $2.9 \pm 0.65$ & $5.1 \pm 1.06$ & $0.2 \pm 0.13$ & $25.1 \pm 4.04$ & $44.7 \pm 2.87$ & $4.9 \pm 2.26$ & $0.9 \pm 0.64$ & $2.0 \pm 0.23$ & $0.6 \pm 0.40$ \\
\hline 4 & $10.4 \pm 1.54$ & $11.6 \pm 1.72$ & $8.1 \pm 0.66$ & $5.0 \pm 0.31$ & & $3.0 \pm 0.72$ & $4.1 \pm 0.78$ & $0.0 \pm 0.01$ & $35.8 \pm 5.80$ & $34.3 \pm 3.20$ & $7.4 \pm 2.84$ & $1.3 \pm 0.55$ & $2.2 \pm 0.57$ & $2.4 \pm 1.93$ \\
\hline 5 & $15.0 \pm 1.89$ & $13.1 \pm 1.78$ & $10.3 \pm 0.63$ & & & $0.8 \pm 0.28$ & $1.8 \pm 0.62$ & $0.3 \pm 0.21$ & $48.8 \pm 5.75$ & $49.6 \pm 4.98$ & $5.8 \pm 3.25$ & $2.5 \pm 2.25$ & $5.0 \pm 0.51$ & $0.8 \pm-.48$ \\
\hline 6 & $20.2 \pm 1.89$ & $10.0 \pm 1.50$ & $11.6 \pm 0.55$ & & & $0.6 \pm 0.50$ & $1.0 \pm 0.55$ & $0.3 \pm 0.14$ & $40.7 \pm 4.76$ & $57.7 \pm 2.68$ & $8.0 \pm 3.66$ & $3.7 \pm 1.96$ & & \\
\hline 7 & & $15.0 \pm 2.59$ & $12.5 \pm 0.25$ & & & $4.2 \pm 2.60$ & $2.2 \pm 0.58$ & $0.0 \pm 0.01$ & $44.5 \pm 3.43$ & $61.6 \pm 6.29$ & $11.3 \pm 5.63$ & $0.6 \pm 0.46$ & & \\
\hline 8 & & & $13.8 \pm 0.65$ & & & $4.0 \pm 0.40$ & $11.8 \pm 2.69$ & $0.8 \pm 0.63$ & $58.9 \pm 4.68$ & $66.0 \pm 4.07$ & $15.3 .902 \pm$ & $3.7 \pm 0.98$ & & \\
\hline 9 & & & & & & $0.0 \pm 0$ & $0.7 \pm 0.37$ & $5.4 \pm 1.33$ & & & & & & \\
\hline 10 & & & & & & & & $6.6 \pm 3.33$ & & & & & & \\
\hline 11 & & & & & & & & $6.4 \pm 2.82$ & & & & & & \\
\hline
\end{tabular}


Table 3. Mean ( \pm s.e.) percentage of rodent damaged grains sub-sampled from baskets placed in farmer granaries in Bangladesh and Myanmar

\begin{tabular}{|c|c|c|c|c|c|c|c|c|c|c|c|c|c|c|}
\hline \multirow[b]{2}{*}{$\begin{array}{l}\text { Sampling } \\
\text { interval }\end{array}$} & \multicolumn{5}{|c|}{ Bangladesh, Feb-May 2009} & \multicolumn{3}{|c|}{ Myanmar, Feb-Sep 2013} & \multicolumn{4}{|c|}{ Bangladesh, Jun-Sep 2010} & \multicolumn{2}{|c|}{ Myanmar, May-Aug 2007} \\
\hline & Anandapur & Kaliganj & Mirpur & Purbadhala & Shibgonj & $\begin{array}{c}\text { Ma-ubin } \\
\text { Nyaung } \\
\text { Wine }\end{array}$ & $\begin{array}{l}\text { Ma-ubin } \\
\text { Pan Pin Su }\end{array}$ & $\begin{array}{c}\text { Daik-U } \\
\text { Phaung } \\
\text { Wei }\end{array}$ & $\begin{array}{l}\text { Haripur } \\
\text { control }\end{array}$ & $\begin{array}{c}\text { Chandina } \\
\text { control }\end{array}$ & $\begin{array}{c}\text { Barura } \\
\text { treatment }\end{array}$ & $\begin{array}{l}\text { Laksham } \\
\text { treatment }\end{array}$ & $\begin{array}{l}\text { Myaungmya } \\
\text { control }\end{array}$ & $\begin{array}{c}\text { Myaungmya } \\
\text { treatment }\end{array}$ \\
\hline 0 & $0.0 \pm 0$ & $0.0 \pm 0$ & $0.0 \pm 0$ & $0.0 \pm 0$ & $0.0 \pm 0$ & $0.0 \pm 0$ & $0.0 \pm 0$ & $0.0 \pm 0$ & $0.0 \pm 0$ & $0.0 \pm 0$ & $0.0 \pm 0$ & $0.0 \pm 0$ & $0.0 \pm 0$ & $0.0 \pm 0$ \\
\hline 1 & $1.8 \pm 0.41$ & $7.3 \pm 1.05$ & $6.7 \pm 0.71$ & $0.6 \pm 0.17$ & $18.1 \pm 2.56$ & $0.0 \pm 0$ & $0.0 \pm 0$ & $0.7 \pm 0.33$ & $4.1 \pm 1.43$ & $9.9 \pm 2.31$ & $0.6 \pm 0.31$ & $0.2 \pm 0.10$ & $0.0 \pm 0$ & $0.0 \pm 0$ \\
\hline 2 & $4.4 \pm 0.84$ & $7.6 \pm 1.37$ & $9.1 \pm 0.79$ & $3.1 \pm 0.20$ & $16.5 \pm 1.42$ & $0.0 \pm 0$ & $0.0 \pm 0$ & $0.0 \pm 0$ & $3.5 \pm 1.47$ & $12.2 \pm 2.09$ & $1.1 \pm 0.46$ & $0.4 \pm 0.20$ & $0.0 \pm 0$ & $0.0 \pm 0$ \\
\hline 3 & $6.9 \pm 0.96$ & $7.2 \pm 1.28$ & $9.9 \pm 0.80$ & $4.4 \pm 0.32$ & $22.0 \pm 1.50$ & $1.3 \pm 1.09$ & $0.1 \pm 3.19$ & $0.4 \pm 0.04$ & $6.7 \pm 1.67$ & $13.0 \pm 2.48$ & $0.6 \pm 0.57$ & $0.2 \pm 0.16$ & $0.6 \pm 0.05$ & $0.2 \pm 0.03$ \\
\hline 4 & $7.4 \pm 0.90$ & $8.2 \pm 1.82$ & $11.9 \pm 0.89$ & $5.0 \pm 0.36$ & & $1.8 \pm 0.60$ & $4.6 \pm 1.88$ & $0.0 \pm 0$ & $6.2 \pm 1.39$ & $13.8 \pm 3.26$ & $1.1 \pm 0.57$ & $0.1 \pm 0.04$ & $0.2 \pm 0.01$ & $0.4 \pm 0.03$ \\
\hline 5 & $10.4 \pm 0.92$ & $9.6 \pm 1.25$ & $11.7 \pm 0.93$ & & & $0.6 \pm 0.10$ & $3.5 \pm 0.24$ & $3.2 \pm 2.17$ & $14.4 \pm 1.55$ & $25.0 \pm 5.06$ & $1.6 \pm 0.76$ & $0.4 \pm 0.27$ & $0.0 \pm 0$ & $0.0 \pm 0$ \\
\hline 6 & $15.1 \pm 1.33$ & $16.6 \pm 3.00$ & $12.0 \pm 0.79$ & & & $0.1 \pm 0.77$ & $2.4 \pm 1.85$ & $0.3 \pm 0.30$ & $17.1 \pm 2.36$ & $31.2 \pm 4.25$ & $1.4 \pm 0.54$ & $0.4 \pm 0.16$ & & \\
\hline 7 & & $8.8 \pm 1.84$ & $11.0 \pm 0.44$ & & & $0.9 \pm 0.11$ & $2.9 \pm 2.78$ & $0.3 \pm 0.33$ & $36.4 \pm 5.36$ & $34.4 \pm 3.54$ & $1.8 \pm 0.64$ & $0.5 \pm 0.28$ & & \\
\hline 8 & & & $12.9 \pm 0.32$ & & & $1.8 \pm 6.99$ & $6.9 \pm 7.97$ & $0.0 \pm 0$ & $39.9 \pm 5.69$ & $37.4 \pm 4.12$ & $5.2 \pm 0.90$ & $1.7 \pm 0.33$ & & \\
\hline 9 & & & & & & $7.1 \pm 0$ & $14.8 \pm 5.21$ & $0.0 \pm 0$ & & & & & & \\
\hline 10 & & & & & & & & $0.2 \pm 0.20$ & & & & & & \\
\hline 11 & & & & & & & & $0.4 \pm 0.34$ & & & & & & \\
\hline
\end{tabular}


20

\begin{tabular}{ccccccccc}
\hline \multirow{2}{*}{ Country } & $\begin{array}{c}\text { Community } \\
\text { intervention }\end{array}$ & \multicolumn{3}{c}{ Farmer loss in kg } & \multicolumn{4}{c}{$\begin{array}{c}\text { Farmer loss as percentage of } \\
\text { total grain volume stored }\end{array}$} \\
& 30 days & 60 days & 90 days & 30 days & 60 days & 90 days \\
\hline \multirow{2}{*}{ Bangladesh } & No trapping & 8.06 & 16.13 & 24.19 & 0.84 & 1.68 & 2.53 \\
& With trapping & 1.79 & 3.58 & 5.37 & 0.16 & 0.32 & 0.49 \\
\hline \multirow{2}{*}{ Myanmar } & No trapping & 44.09 & 88.18 & 132.27 & 5.88 & 11.77 & 17.65 \\
& With trapping & 26.12 & 52.24 & 78.36 & 1.78 & 3.57 & 5.35 \\
\hline
\end{tabular}

Table 4. Mean amount of grain that farmers in Bangladesh (2010 data) and Myanmar (2007 data) can expect to lose from their stored rice stocks over time to rodents

21 


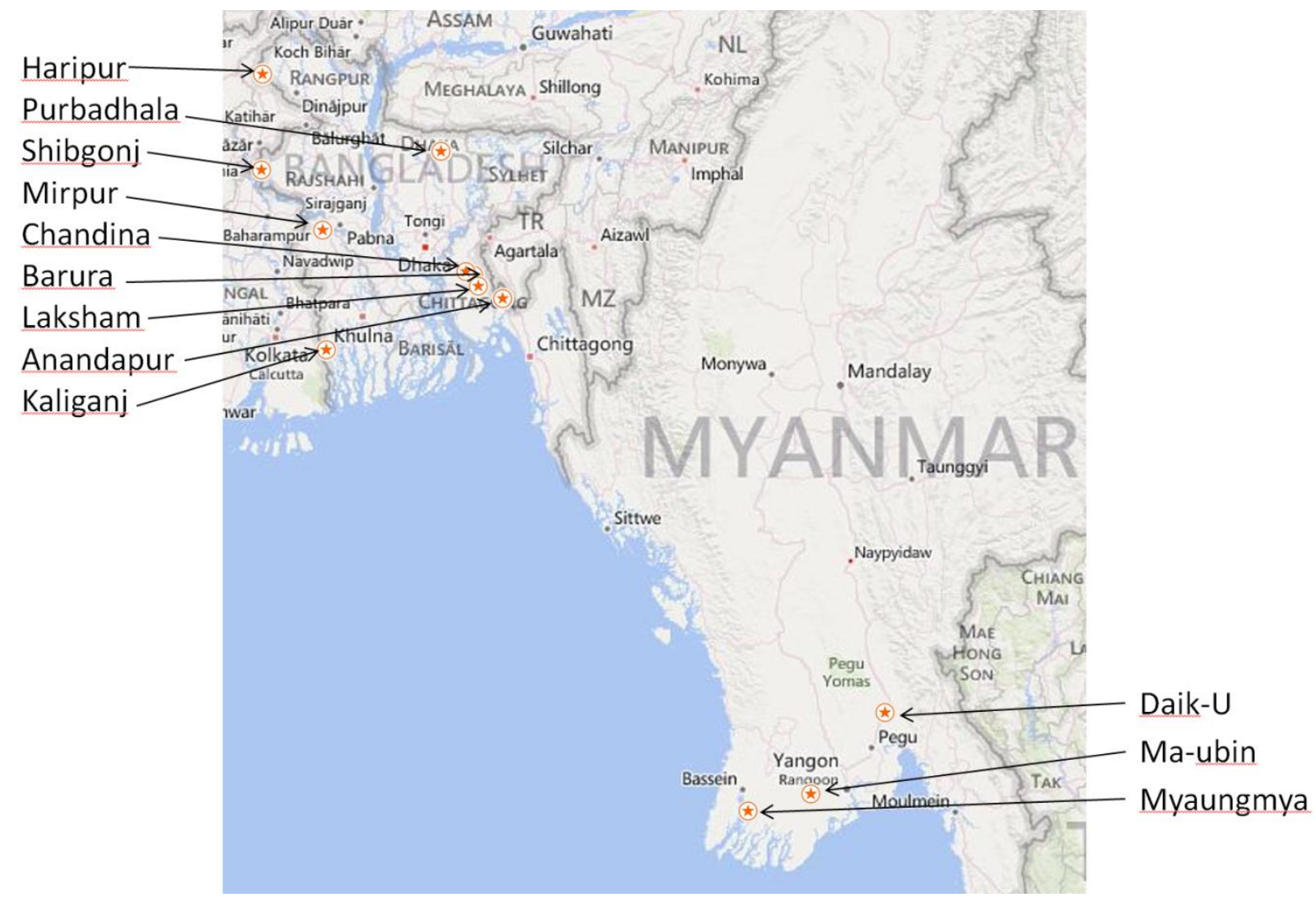

Fig 1. Loss assessment and rodent management survey locations in Bangladesh and Myanmar 

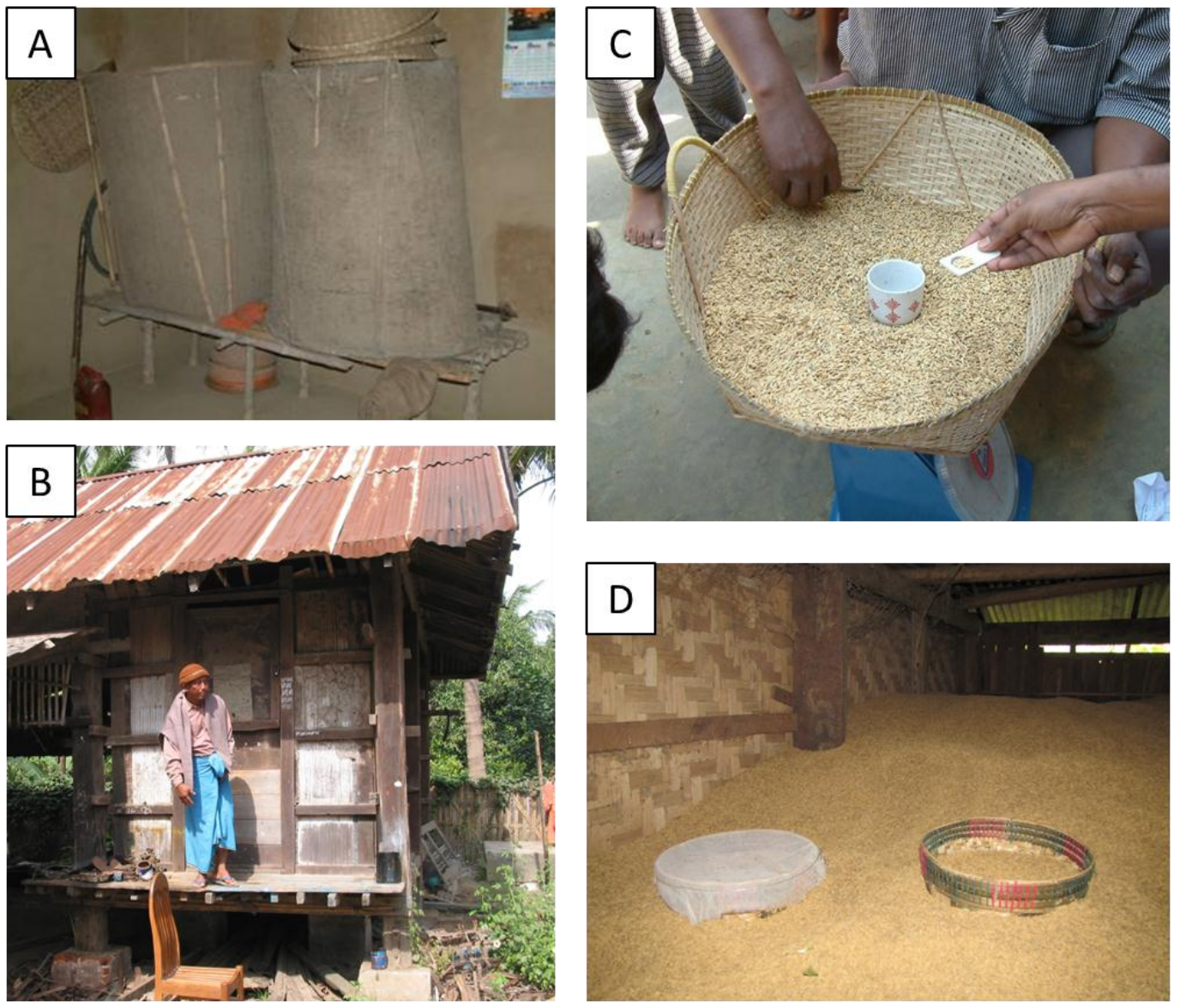

Fig 2. Example of A) household grain store inside a house in Bangladesh; B) granary building in Myanmar; C) basket used for trials in Bangladesh; D) baskets used for trials in Myanmar 
A)

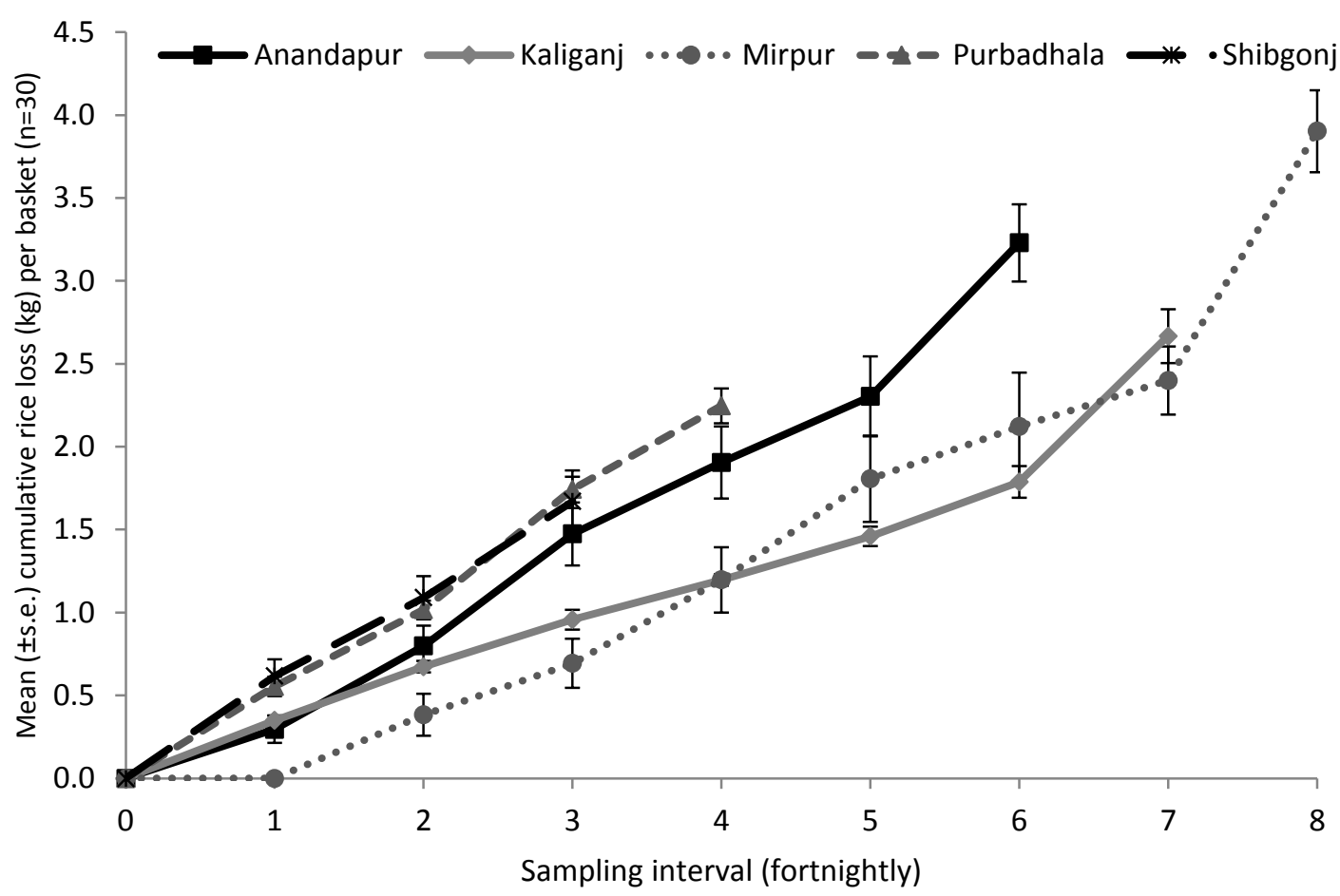

B)

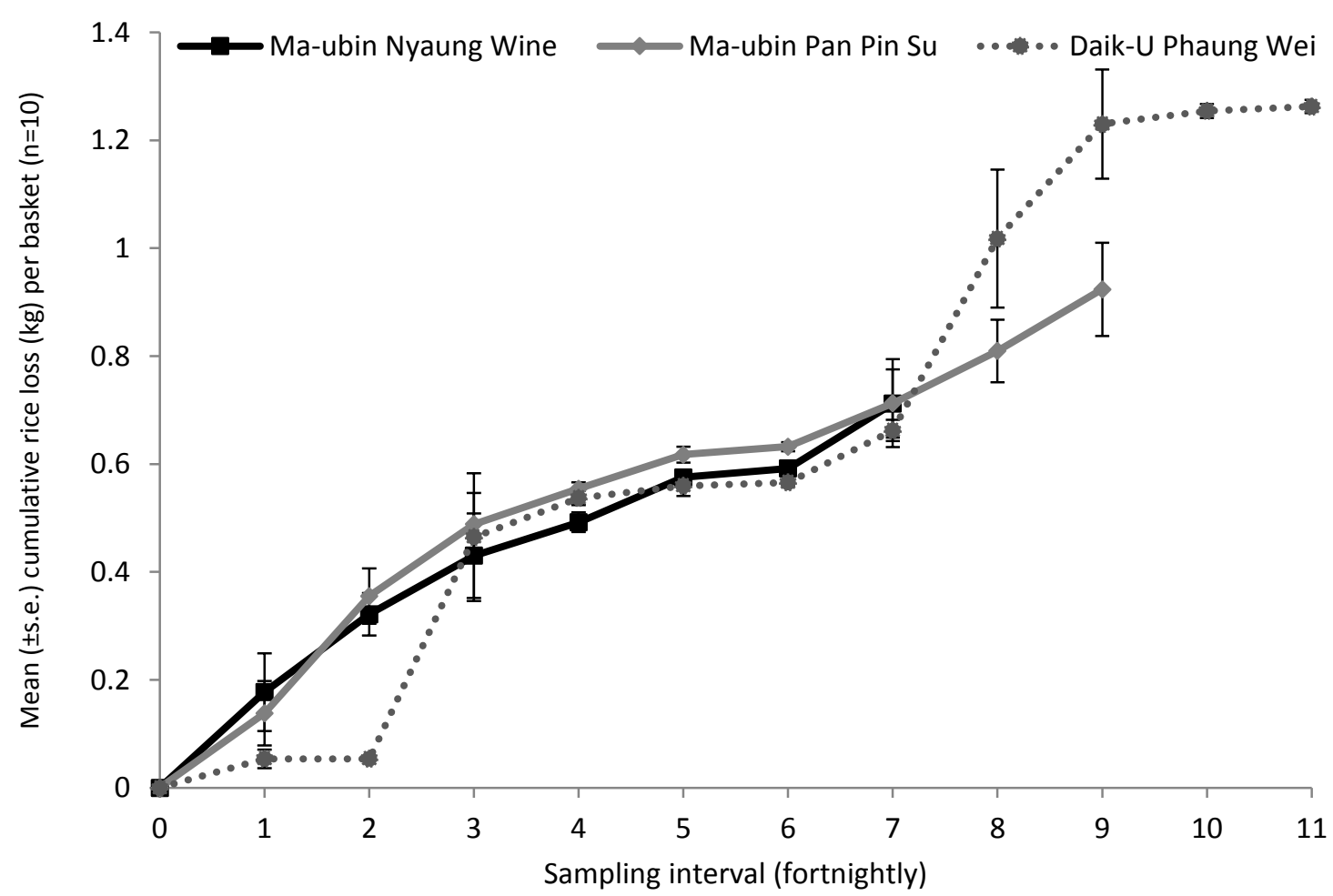

Fig 3. Cumulative loss of stored rice removed by rodents from baskets placed in A) farmer stores over February to May 2009 in Bangladesh communities; B) farmer granaries from February to September 
A)

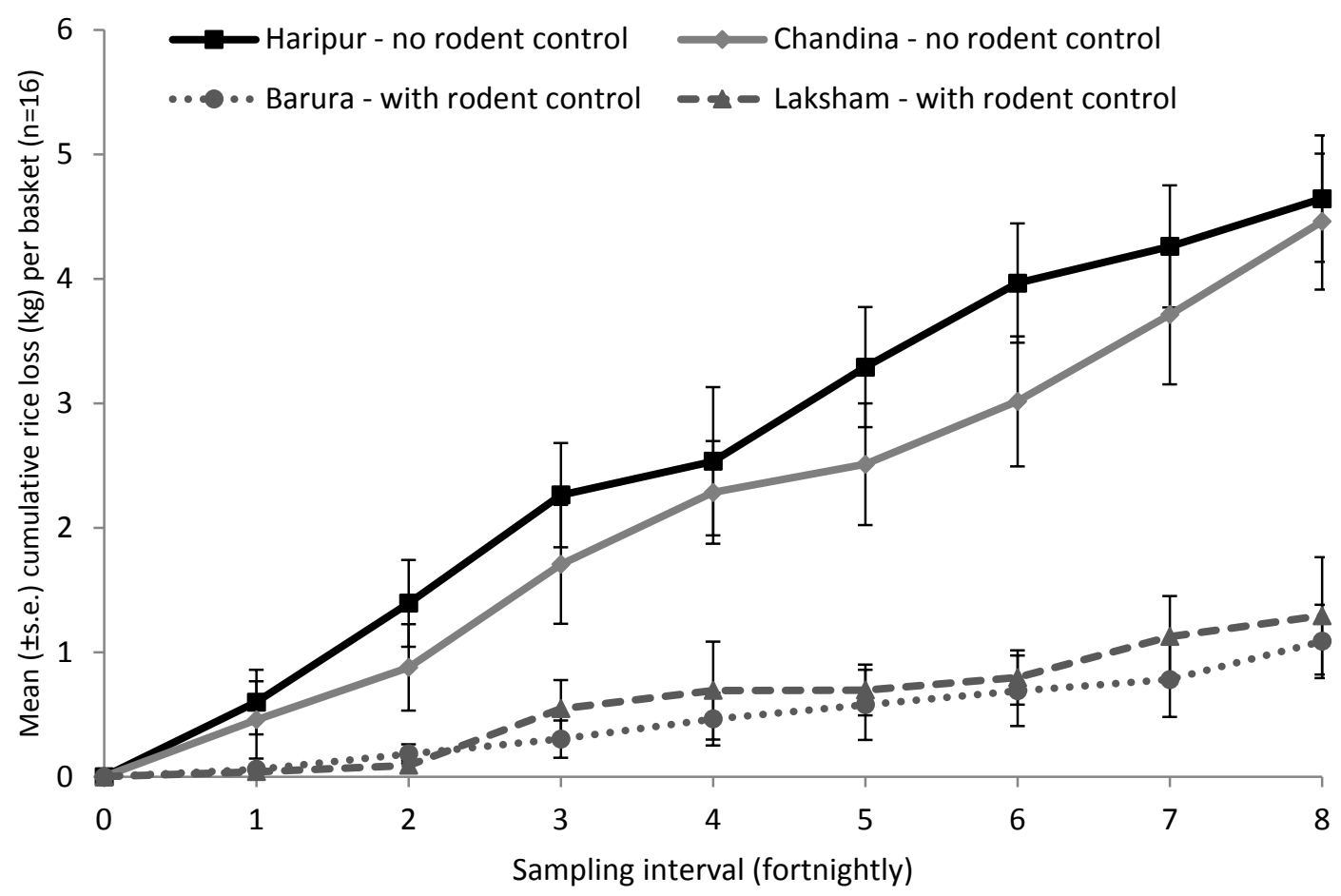

B)

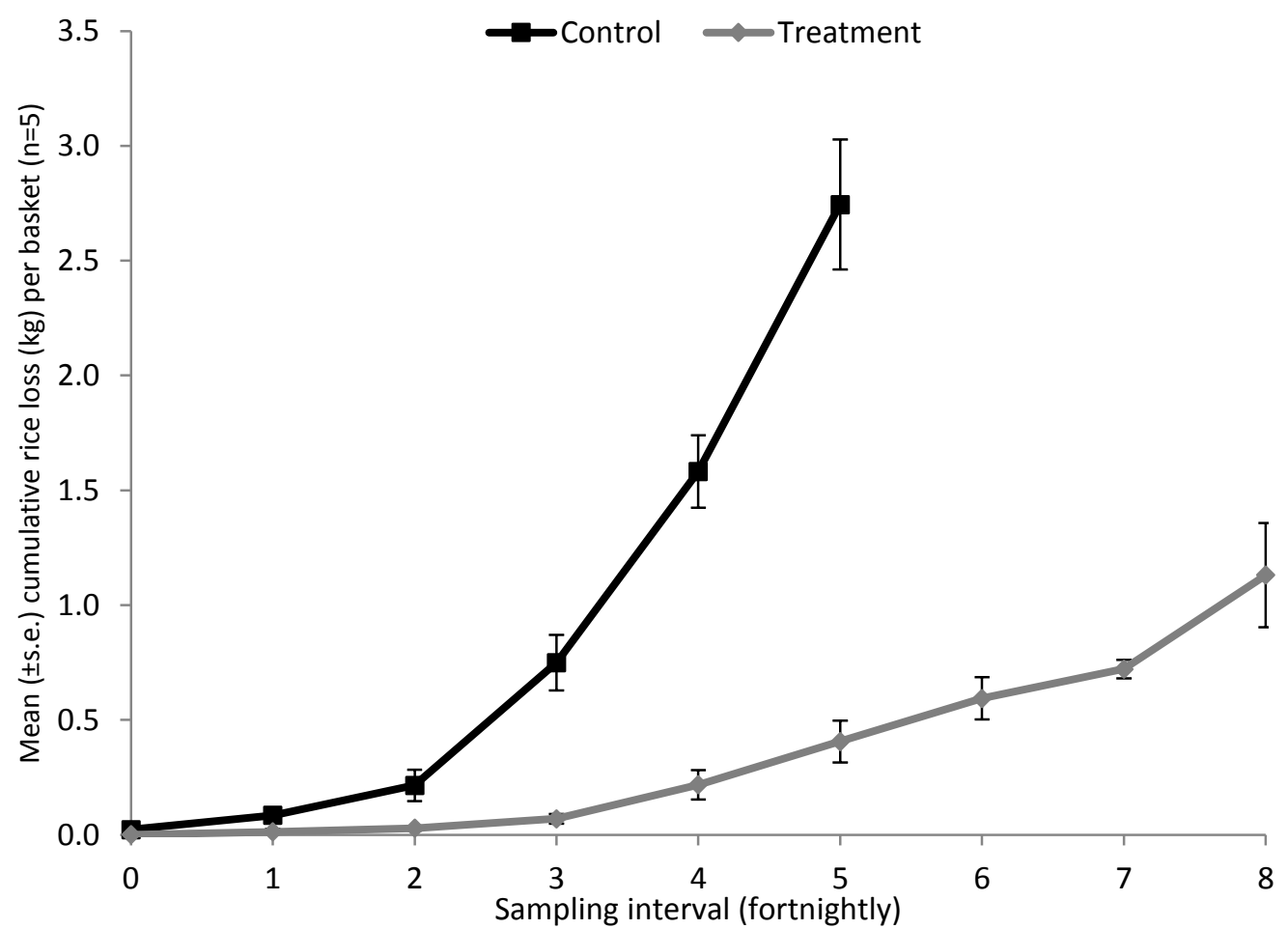

Fig 4. Rice removed by rodents from baskets placed in A) farmer stores over June to September 2010 in Bangladesh communities; B) farmer granaries over May to August 2007 in the village of Myaungmya, Myanmar where granaries had either adopted a rodent management strategy which included sanitation and rodent trapping (treatment) or followed traditional practice (control) 

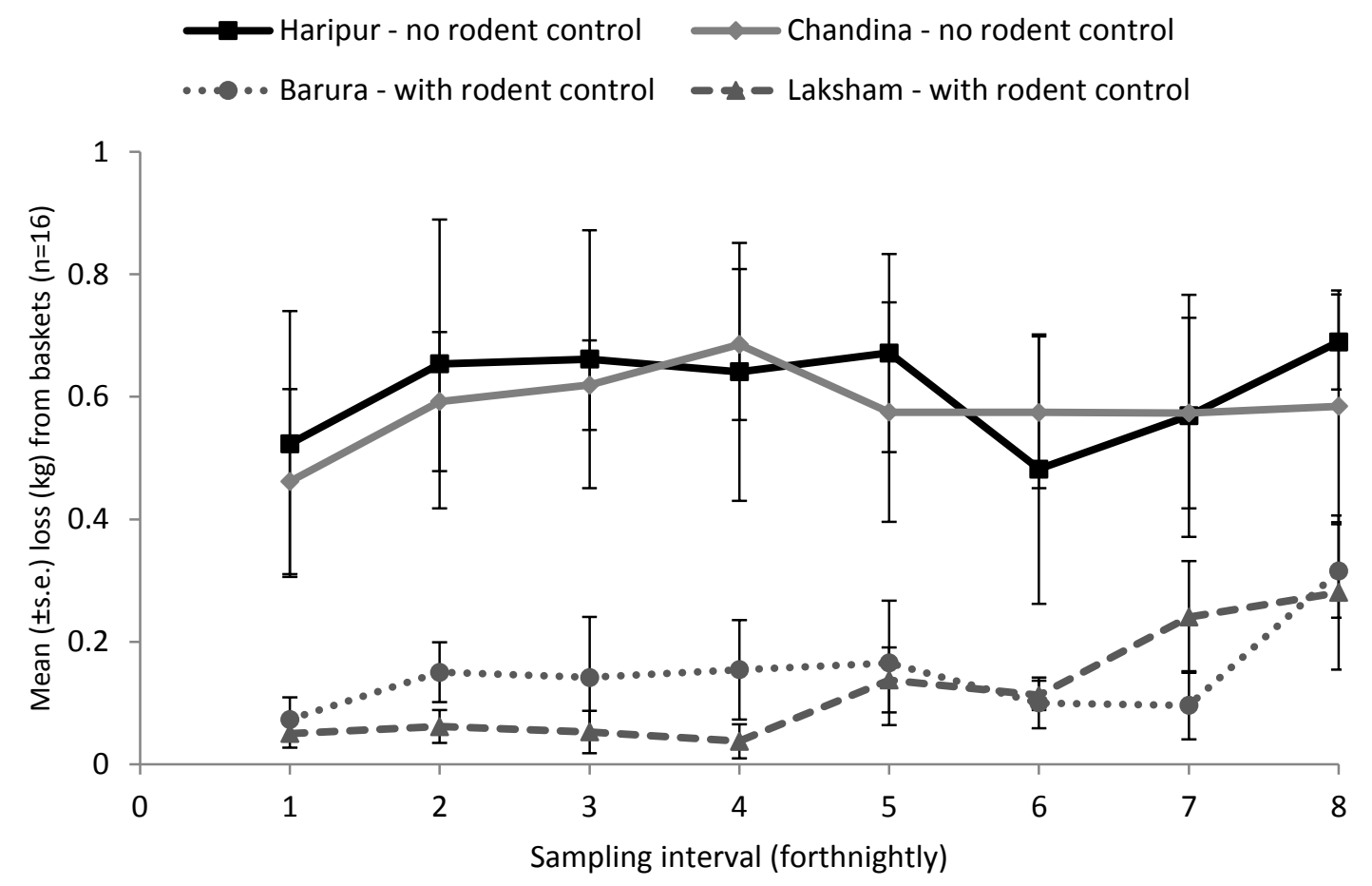

57

58 Fig 5. Rice removed from baskets by rodents in between assessment intervals over June to September 592010 in Bangladesh communities

60

61 